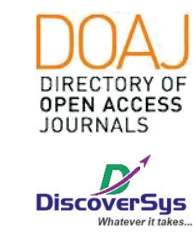

Published by DiscoverSys

\section{Hubungan kadar serum gamma-glutamyl transferase dengan profil lipid pada Diabetes Melitus-Tipe 2 (DM-2) terkontrol dan tidak terkontrol di Rumah Sakit Umum Pusat Haji, Adam Malik Medan, Indonesia}

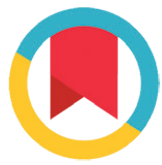

CrossMark

\author{
Furiyani, ${ }^{1 *}$ Santi Syafril, ${ }^{2}$ Burhanuddin $\mathrm{Nst}^{3}$
}

\title{
ABSTRACT
}

Background: Diabetes mellitus is a group of metabolic diseases with characteristics of hyperglycemia that occur due to impaired insulin secretion, insulin work, or both whereas also impaired lipid peroxidation caused by oxidative stress. Gamma-glutamyl transferase (GGT) is an enzyme on the surface of the cell membrane that is responsible for the catabolism of glutathione which acts as a marker of oxidative stress. This study aims to determine the relationship of serum GGT levels with lipid profiles in controlled and uncontrolled type $2 \mathrm{DM}$. Method: A cross-sectional study was conducted at H. Adam Malik General Hospital Medan from September - November 2018 among 60 patients with type 2 DM grouped according to $\mathrm{HbA} 1 \mathrm{c}<7 \%$ controlled and $\mathrm{HbA1C}>7 \%$ uncontrolled. GGT levels and lipid profiles examined using enzymatic calorimetry and $\mathrm{HbA1c}$ with Immunoturbidimetry method. The relationship of serum GGT levels with lipid profiles in controlled DM-2 was tested using the Pearson correlation test whereas controlled DM-2 correlation test using the Spearman's correlation test using SPSS version 21 for Windows.

Results: Most of respondents were males with HbA1C levels $<7 \%$ $(53.3 \%)$ and $\mathrm{HbA1C} \geq 7 \%(60.0 \%)$. There was no difference in the mean age and serum GGT levels between uncontrolled DM-2 or controlled $D M-2$ group $(P=0.260$ and $P=0.520$, respectively). There was no association between serum GGT levels and lipid profiles in the controlled type $2 \mathrm{DM}$ group and uncontrolled type $2 \mathrm{DM}$. ( $r=P>0.05)$. Conclusion: There is no significant relationship between serum GGT levels and lipid profiles in controlled and uncontrolled type 2 DM groups.

Keywords: Type 2 DM-2, HbA1C, GGT, Lipid profile

Cite This Article: Furiyani, Syafril, S., Burhanuddin N.S.T. 2019. Hubungan kadar serum gamma-glutamyl transferase dengan profil lipid pada Diabetes Melitus-Tipe 2 (DM-2) terkontrol dan tidak terkontrol di Rumah Sakit Umum Pusat Haji, Adam Malik Medan, Indonesia. Intisari Sains Medis 10(3): 487-491. D0I: 10.15562/ism.v10i3.426

\section{ABSTRAK}

'Departemen Patologi Klinik, Fakultas Kedokteran Universitas Sumatera Utara/RSUP Haji Adam Malik Medan, Indonesia

${ }^{2}$ Departemen IImu penyakit Dalam, Fakultas Kedokteran Universitas Sumatera Utara/RSUP Haji Adam Malik Medan, Indonesia ${ }^{3}$ Divisi Kimia Klinik, Departemen Patologi Klinik Fakultas Kedokteran Universitas Sumatera Utara/RSUP Haji Adam Malik Medan, Indonesia

*Korespondensi: Furiyani; Departemen Patologi Klinik, Fakultas Kedokteran Universitas Sumatera Utara/RSUP Haji Adam Malik Medan, Indonesia;

furiyani6@gmail.com
Pendahuluan: Diabetes mellitus merupakan suatu kelompok metabolik dengan karakteristik hiperglikemia yang terjadi karena sekresi insulin, kerja insulin atau kedua-duanya dimana juga mengganggu peroksidasi lipid disebabkan stress oksidatig. Gammaglutamyl transferase (GGT) merupakan enzim pada permukaan membran sel yang bertanggung jawab terhadap katabolisme gluthatione yang berperan sebagai penanda stres oksidatif. Penelitian ini bertujuan untuk mengetahui hubungan kadar serum GGT dengan profil lipid pada DM tipe 2 terkontrol dan tidak terkontrol.

Metode: Suatu studi potong lintang dilakukan di RSUP H. Adam Malik Medan dari September-November 2018 terhadap 60 penderita DM tipe 2 yang diklasifikasikan berdasarkan $\mathrm{HbA1c}<7 \%$ terkontrol dan $>7 \%$ tidak terkontrol kadar GGT dan profil lipid diperiksa menggunakan kolorimetri enzimatik dan $\mathrm{HbA1c}$ dengan metode
Immunoturbidimetri. Hubungan kadar serum GGT dengan profil lipid pada DM tipe 2 terkontrol menggunakan uji korelasi Pearson DM tipe 2 tidak terkontrol mengunakan uji korelasi Spearmans menggunakan SPSS versi 21 untuk Windows.

Hasil: Sebagian besar pasien berjenis kelamin laki-laki memiliki kadar $\mathrm{HbA1C}<7 \%(53,3 \%)$ maupun $\mathrm{HbA1C} \geq 7 \%$ (60,0\%). Tidak terdapat perbedaan rata-rata usia dan kadar serum GGT pada kelompok DM-2 tidak terkontrol maupun $\mathrm{DM}-2$ terkontrol $(\mathrm{P}=0,260$ dan $\mathrm{P}=0,520$, berturut-turut). Tidak dijumpai hubungan kadar serum GGT dengan profil lipid pada kelompok DM tipe 2 terkontrol dan DM tipe 2 tidak terkontrol. ( $P>0.05)$.

Kesimpulan: Tidak terdapat hubungan bermakna kadar serum GGT dengan profil lipid pada kelompok DM tipe 2 terkontrol dan tidak terkontrol. 


\section{PENDAHULUAN}

Diabetes mellitus (DM) merupakan suatu kelompok penyakit metabolik dengan karakteristik hiperglikemi yang terjadi oleh karena kelainan sekresi insulin, kerja insulin atau kedua-duanya. ${ }^{1}$ Prevalensinya semakin meningkat dari tahun ke tahun. DM terjadi akibat pankreas tidak mampu menghasilkan insulin yang cukup atau ketika tubuh tidak dapat secara efektif menggunakan insulin, hal ini akan menyebabkan peningkatan konsentrasi glukosa atau hiperglikemia yang disertai gangguan metabolisme karbohidrat, lemak dan protein. ${ }^{1}$

International Diabetes Federation (IDF) menyebutkan bahwa terdapat 415 juta penduduk dunia dengan diabetes pada tahun 2015 dengan usia rata-rata 20-79 tahun. $^{2}$ Jumlah tersebut akan terus meningkat dan diperkirakan 642 juta penderita DM pada tahun 2040 dari jumlah tersebut 175 juta di antaranya belum terdiagnosis sehingga terancam berkembang progresif terjadi komplikasi tanpa disadari. ${ }^{2}$ Indonesia sendiri DM tipe 2 menduduki peringkat ketujuh didunia setelah China, India, Amerika serikat, Brazil, Rusia dan Mexico. WHO memprediksikan kenaikan jumlah penderita DM di Indonesia sekitar 21,3 juta pada tahun 2030 dari 8,4 juta pada tahun $2000 .^{3}$

Cedera vaskular pada diabetes akibat dari hiperglikemia telah dikaitkan dengan stres oksidatif yang menyebabkan deplesi glutathione intraseluler dengan meningkatnya superoksida dismutase ekstaseluler plasma yang menghalangi peroksidasi lipid dan komplikasi diabetes. ${ }^{4}$ Hiperglikemia pada DM akan meingkatkan Reactive Oxygen Species (ROS) yang toksik melebihi pertahanan antioksidan endogen yang akan menyebabkan stres oksidatif. Hal ini jika terjadi berkepanjangan akan menyebabkan kerusakan sel dan jaringan. ${ }^{5}$

GGT merupakan protein permukaan sel yang terdapat pada berbagai jaringan. GGT sebagian besar diproduksi di dalam sel hepar dan hepar tempat aktivitas utamanya dengan memamfaatkan gluthatione sebagai antioksidan intraseluler sel yang berperan penting dalam perlindungan sel terhadap radikal bebas. ${ }^{6}$

Beberapa parameter laboratorium telah menunjukkan bahwa terdapat hubungan antara profil lipid terhadap kontrol gula darah pada pasien DM-2.6,7 Salah satu yang berperan adalah perubahan kadar GGT. Peningkatan GGT menunjukkan kompensasi mekanisme anti oksidan melawan stres oksidatif terutama pada pasien dengan hiperglikemia. ${ }^{8}$ GGT memainkan peran penting dalam homeostasis glutathione intraseluler untuk mengatasi stres oksidatif. Pada penderita DM tipe 2 GGT juga menunjukkan korelasi positif dengan profil lipid sehingga diharapkan GGT dapat di eksploitasi sebagai biomarker aterogenik sederhana pengganti profil lipid. ${ }^{8} \mathrm{Di}$ samping itu, GGT juga merupakan prediktor kuat untuk DM dan dislipidemia. GGT diduga berperan dalam patogenesis aterosklerosis pada penderita DM tipe 2 melalui mekanisme inflamasi dan stres oksidatif oleh karena hiperglikemia. ${ }^{4}$

Berkaitan dengan pemaparan di atas maka penelitian ini bertujuan untuk mengetahui hubungan kadar serum gamma-glutamyl transferase dengan profil lipid pada pasien dengan diabetes melitus-tipe 2 (DM-2) yang terkontrol dan tidak terkontrol di Rumah Sakit Umum Pusat Haji, Adam Malik Medan, Indonesia

\section{METODE}

Penelitian dilakukan dengan metode observasional analitik korelatif dengan pendekatan potong lintang untuk mengatahui hubungan kadar serum GGT dengan profil lipid pada DM tipe 2 kelompok terkontrol dan tidak terkontrol. Peneltian ini dilakukan pada bulan September sampai dengan November 2018 di Divisi Endokrinologi Departemen Penyakit Dalam FK-USU/RSUP. H. Adam Malik Medan.

Populasi target pada penelitian adalah penderita DM tipe 2 berdasarkan kriteria Perkeni 2015 yang berkunjung ke Poliklinik Endokrinologi Departemen Penyakit Dalam RSUP Haji Adam Malik Medan. Subjek adalah populasi terjangkau yang memenuhi kriteria inklusi dan ekslusi dan dipilih dengan teknik consecutive sampling. Adapun beberapa kriteria inklusi pada penelitian ini meliputi seluruh penderita DM tipe-2, pasien berusia $\geq 40$ tahun, serta memberikan persetujuan untuk ikut serta dalam penelitian ini. Sedangkan kriteria eksklusi pada penelitian ini adalah wanita hamil, penderita DM-2 dengan berbagai kontraindikasi (peminum alkohol, riwayat penyakit jantung, kadar AST atau ALT meningkat tiga kali nilai normal, anemia), perokok aktif, maupun sedang menggunakan obat antioksidan atau anti-lipid.

Analisis univariat dan bivariat dilakukan terhadap data penelitian. Untuk data demografis dilakukan analisis univariat sehingga didapatkan distribusi karakteristik subjek penelitian. Analisis bivariat digunakan untuk mengetahui perbedaan rerata kadar serum GGT pada kelompok DM tipe 2 terkontrol dan tidak terkontrol menggunakan uji T-independent. Untuk melihat hubungan kadar GGT dan profil lipid pada pasien DM tipe 2 terkontrol dan tidak terkontrol dipakai uji korelasi 
Pearson untuk data yang berdistribusi normal dan bila tidak berdistribusi normal digunakan uji Spearman. Hasil test dikatakan bermakna bila nilai $<<0,05$ pada piranti lunak SPSS versi 21 untuk Windows.

\section{HASIL}

Penelitian ini diikuti oleh 60 subjek DM tipe 2 yang telah memenuhi kritera insklusi dan eksklusi yang terdiri dari 30 subjek DM tipe 2 terkontrol dengan HbAlc $<7 \%$ dan 30 subjek DM tipe 2 tidak terkontrol dengan $\mathrm{HbA1c}>7 \%$. Data dengan skala ukur numerik diuji normalitas dengan menggunkan uji Kolmogorov-Smirnov dan analisis univariat untuk mengetahui distribusi karakteristik sampel dengan hasil seperti yang tertera pada Tabel 1 .

Hasil penelitian menunjukkan bahwa jenis kelamin laki-laki menempati proporsi terbanyak dibandingkan perempuan baik pada kelompok DM-2 terkontrol $(53,3 \%)$ maupun yang tidak terkontrol (60,0\%). Sedangkan dari faktor usia diketahui rata-rata berusia $55,0 \pm 7,1$ tahun pada kelompok DM-2 terkontrol dan 53,3 $\pm 6,0$ tahun pada kelompok DM-2 yang tidak terkontrol dimana tidak terdapat perbedaan bermakna (P-0,260). Akan tetapi kadar HbA1C menunjukkan perbedaan bermakna antara kedua kelompok
DM-2 $(\mathrm{P}=0,001)$. Kemudian kadar serum GGT menunjukkan kecenderungan rerata lebih tinggi pada kelompok DM-2 tidak terkontrol $(59,26 \pm 21$, $37 \mathrm{mg} / \mathrm{dL}$ ) dibandingkan kelompok DM-2 terkontrol $(55.83 \pm 19.65 \mathrm{mg} / \mathrm{dL})$ meskipun secara statistik tidak bermakna $(\mathrm{P}=0,520)$.

Tahap selanjutnya dilakukan analisis bivariat untuk mengetahui hubungan kadar serum GGT dengan profil lipid pada kelompok DM tipe 2 terkontrol dan tidak terkontrol. Hasil menunjukkan bahwa secara keseluruhan baik pemeriksaan total kolesterol, trigliserida, HDL, maupun LDL tidak menunjukan korelasi secara bermakna terhadap kadar serum GGT baik pada kelompok DM-2 terkontrol maupun tidak terkontrol $(\mathrm{P}>0,05)$ (Tabel 2).

\section{PEMBAHASAN}

Peneitian ini dilakukan sejak bulan September sampai November 2018. Pada penelitian ini dikumpulkan 60 subjek penderita DM tipe 2 yang dibagi kedalam dua kelompok DM tipe 2 terkontrol $(\mathrm{HbA} 1 \mathrm{c}<7 \%)$ dan kelompok tidak terkontrol (HbAlc $>7 \%)$. Hasil penelitian yang telah dilakukan menunjukkan bahwa tidak terdapat perbedaan bermakna antara kadar GGT pada kelompok DM tipe 2 terkontrol dan DM tipe 2 tidak terkontrol .

\section{Tabel 1 Karakteristik Umum Pasien DM tipe 2}

\begin{tabular}{lccc}
\hline & \multicolumn{2}{c}{ Diabetes Melitus Tipe-2 (DM-2) } \\
\cline { 2 - 3 } Karakteristik & $\begin{array}{c}\text { Terkontrol }(\mathbf{n = 3 0}) \\
\text { HbA1c }<\mathbf{7 \%}\end{array}$ & $\begin{array}{c}\text { Tidak terkontrol }(\mathbf{n}=\mathbf{3 0}) \\
\text { HbA1c } \geq \mathbf{7 \%}\end{array}$ & P \\
\hline Jenis Kelamin (\%) & & & \\
$\quad$ Laki-laki & $16(53.3 \%)$ & $18(60.0 \%)$ & - \\
$\quad$ Perempuan & $14(46.7 \%)$ & $12(40.0 \%)$ & $0,260^{\mathrm{a}}$ \\
Umur (Rerata \pm SB)(Tahun) & $55,0 \pm 7,1$ & $53,3 \pm 6,0$ & $0,001^{\mathrm{b}}$ \\
HbA1c (\%)(median,min-max) & $6,6(5.5-6,9)$ & $8.35(7,3-11,4)$ & $0,520^{\mathrm{a}}$ \\
Serum GGT (mg/dL)(Rerata \pm SB) & $55.83 \pm 19.65$ & $59,26 \pm 21,37$ & \\
\hline
\end{tabular}

${ }^{a}$ Uji T-independent: bermakna secara statistik apabila $\mathrm{P}<0,05$

bUji Mann-Whitney: bermakna secara statistik apabila $\mathrm{P}<0,05$

Tabel 2 Hubungan kadar serum GGT dengan profil lipid pada kelompok penderita DM tipe 2 terkontrol ( $\mathrm{HbA} 1 \mathrm{c}<7)$ dan tidak terkontrol ( $\mathrm{HbA} 1 \mathrm{C} \geq 7)$

\begin{tabular}{lccccc}
\hline & \multicolumn{2}{c}{$\begin{array}{c}\text { Serum GGT DM-2 terkontrol } \\
(\mathbf{n = 3 0 )}\end{array}$} & & \multicolumn{2}{c}{$\begin{array}{c}\text { Serum GGT DM-2 tidak terkontrol } \\
(\mathbf{n}=\mathbf{3 0})\end{array}$} \\
\cline { 2 - 4 } \cline { 5 - 6 } Variabel & $\mathbf{r}^{\mathbf{a}}$ & $\mathbf{p}$ & & $\mathbf{r}^{\mathbf{b}}$ & $\mathbf{p}$ \\
\hline Total Kolesterol & -0.310 & 0.095 & & 0.082 & 0.668 \\
Trigliserida & 0.204 & 0.279 & & -0.119 & 0.532 \\
HDL & -0.222 & 0.238 & & -0.052 & 0.784 \\
LDL & -0.193 & 0.307 & & -0.009 & 0.962 \\
\hline
\end{tabular}

$r^{\mathrm{a}}$ : Uji korelasi Pearson; rb: Uji korelasi Spearman; Nilai P dikatakan bermakna apabila $<0,05$; Kekuatan korelasi: 0,0-<0,2:sangat lemah, 0,2-<0,4:lemah, 0,4-<0,6:sedang, 0,6-<0,8:kuat, 0,8-1,0:sangat kuat; HDL: High-Density Lipoprotein; LDL: Low-Density Lipoprotein 
Berkaitan dengan hasil tersebut penulis berasumsi bahwa GGT diduga telah meningkat lebih awal pada kondisi pradiabetes sebagai penanda stres oksidatif karena adanya hiperglikemia. Hal ini didukung oleh bukti yang menunjukkan bahwa kondisi hiperglikemia cenderung mengurangi glutathione hati akibat stres oksidatif dan GGT meningkat untuk mempertahankan tingkat normal glutathione sel dan tidak terdapat perbedaan tingkat kelainan GGT berdasarkan derajat kontrol glikemik serta durasi diabetes. ${ }^{8,9}$

Beberapa faktor yang terkait dengan GGT termasuk diantaranya indek masa tubuh, lingkar pinggang,rasio pinggang terhadap panggul, tekanan darah sistolik dan diastolik dan pengunaa obat-obatan. ${ }^{10}$ Akan tetapi beberapa faktor resiko tersebut tidak dikaji lebih lanjut pada responden penelitian ini sebelumnya, sehingga hubungan kausal sebagai faktor perancu hasil penelitian belum dapat disingkirkan. Di samping itu, pada penelitian ini tidak dijumpai hubungan kolerasi yang bermakna antara kadar serum GGT terhadap profil lipid pada kelompok DM tipe 2 terkontrol dan tidak terkontrol, baik pada hasil pemeriksaan total kolesterol, trigliserida, HDL, maupun LDL. Hal ini sesuai dengan penelitian yang dilakukan oleh Yoon et al yang menunjukkan bahwa pada penderita DM tipe 2 kadar GGT serum tidak menunjukkan hubungan linear dengan kadar profil lemak tubuh namun kadar serum GGT dapat diasumsikan bukan merupakan penanda aterosklerotik subklinis yang dapat di andalkan pada penderita DM tipe 2. ${ }^{11}$ Akan tetapi studi lain menunjukkan bahwa GGT sudah terkandung dalam plak atheroma dimana telah terlebih dahulu menjadi faktor resiko aterosklerotik bahkan sebelum plak terbentuk. ${ }^{12}$ Namun dalam hal ini peneliti berasumsi bahwa hubungan kausal antara kadar serum GGT terhadap profil lipid dan kaitannya dengan resiko aterosklerotik belum dapat disimpulkan pada pasien dengan DM tipe 2 mengingat resiko tersebut tidak dinilai pada studi ini.

\section{SIMPULAN}

Hasil penelitian menunjukkan bahwa tidak terdapat perbedaan kadar serum GGT pada kelompok DM tipe 2 terkontrol dan DM tipe 2 tidak terkontrol berdasarkan parameter HbA1C. Di samping itu, tidak ditemukan perbedaan bermakna antara kadar serum GGT terhadap profil lipid pada kelompok DM tipe 2 terkontrol dan kelompok DM tipe 2 yang tidak terkontrol. Berkaitan dengan hal tersebut, studi lebih lanjut dengan ukuran sampel lebih besar, desain penelitian, maupun preanalitik laboratorium yang baik diperlukan ke depannya.

\section{ETIKA PENELITIAN}

Penelitian ini dilaksanakan setelah mendapat izin dari Komite Etik Penelitian Kesehatan Fakultas Kedokteran Universitas Sumatera Utara, Indonesia sebelum penelitian berjalan.

\section{KONFLIK KEPENTINGAN}

Penulis menyatakan bahwa tidak terdapat konflik kepentingan dalam penulis artikel penelitian ini

\section{PENDANAAN}

Para penulis bertanggung jawab terhadap pendanaan penelitian tanpa melibatkan pihak sponsor atau sumber pendanaan lainnya.

\section{KONTRIBUSI PENULIS}

Furiyani bertanggung jawab dalam pengambilan sampel penelitian, analisis data, hingga interpretasi dan pembuatan laporan akhir penelitian. Santi Syafril dan Burhanuddin Nst bertanggung jawab dalam konsep penelitian dan bertanggung jawab sebagai pembimbing dalam studi ini.

\section{DAFTAR PUSTAKA}

1. Forouhi NG, Wareham NJ. Epidemiology of diabetes. Medicine (Abingdon). 2014; 42(12): 698-702.

2. Cho NH, Shaw JE, Karuranga S, Huang Y, da Rocha Fernandes JD, Ohlrogge AW, et al. IDF Diabetes Atlas: Global estimates of diabetes prevalence for 2017 and projections for 2045. Diabetes Res Clin Pract. 2018;138:271-281

3. Mihardja L, Soetrisno U, Soegondo S. Prevalence and clinical profile of diabetes mellitus in productive aged urban Indonesians. J Diabetes Investig. 2014; 5(5): 507-512.

4. Lee DH, Blomhoff R, Jacobs DR Jr. Is serum gamma glutamyltransferase a marker of oxidative stress?. Free Radic Res. 2004;38(6):535-9.

5. Harris $\mathrm{MI}^{1}$, Flegal KM, Cowie CC, Eberhardt MS, Goldstein DE, Little RR, et al. Prevalence of diabetes, impaired fasting glucose, and impaired glucose tolerance in U.S. adults. The Third National Health and Nutrition Examination Survey, 1988-1994. Diabetes Care. 1998;21(4):518-24.

6. Kashinakunti SV, Kollur PB, Rangappa M, Kallaganada GS. Correlation between Lipid parameters and gamma glutamyl transferase in type 2 diabetes mellitus. International Journal of Clinical Biochemistry and Research 2016;3(3):299-303

7. Artha IMJR, Bhargah A, Dharmawan NK, Pande UW, Triyana KA, Mahariski PA, et al. High level of individual lipid profile and lipid ratio as a predictive marker of poor glycemic control in type- 2 diabetes mellitus. Vascular Health and Risk Management. 2019;15:149-157

8. Bai P, Sandeep F, Kumar S, Shiwlani S, Kumari R, Kumar J. Association of gamma glutamyl transferase and blood lipid levels in type 2 diabetic subjects. Europian journal of pharmaceutical and medical research. 2017;4(8):127-131 
9. Selvam V, Natarajan K, Anbazhagan M, Swaminathan S. Association between Liver enzymes and $\mathrm{HbAlc}$ to lipid profile in Non-hospitalised T2DM patients. Elixir Biosciences. 2017;108:47439-47443.

10. Lee SY, Sung E, Chang Y. Elevated serum gamma-glutamyltransferase is a strong marker of insulin resistance in obese children. Int J Endocrinol. 2013;2013:578693

11. Yoon HE, Mo EY, Shin SJ, Moon SD, Han JH, Kim ES Serum gamma-glutamyltransferase is not associated with subclinical atherosclerosis in patients with type 2 diabetes. Cardiovasc Diabetol. 2016;15(1):108
12. Avogaro A, Albiero M, Menegazzo L, de Kreutzenberg S, Fadini GP. Endothelial dysfunction in diabetes: the role of reparatory mechanisms. Diabetes Care. 2011;34 Suppl 2:S285-90

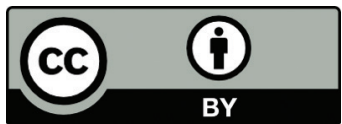

This work is licensed under a Creative Commons Attribution 